\title{
EDYTA KOWALCZYK
}

Uniwersytet Wrocławski

DOI: $10.19195 / 0137-1134.105 .6$

\section{AGRARYZM I JEGO WYRAZ W MYŚLI SPOŁECZNO-EKONOMICZNEJ \\ F. BUJAKA, W. STYSIA I W. GRABSKIEGO}

\section{WPROWADZENIE}

Agraryzm rozwijał się w krajach charakteryzujących się przewagą rolnictwa w strukturze gospodarczej oraz dużą liczbą ludności wiejskiej. Był ideologią, która za swój pierwszoplanowy cel uznawała szeroko rozumianą obronę interesów warstwy chłopskiej. Zgodnie z założeniami agraryzmu rolnictwo stanowiło fundament gospodarki, a chłopi odgrywali wiodącą rolę w życiu społecznym i politycznym kraju. Agraryzm narodził się w Niemczech, skąd rozprzestrzenił się na inne kraje. Na podatny grunt trafił także w Polsce. W okresie dwudziestolecia międzywojennego stanowił jedną z alternatywnych koncepcji organizacji stosunków społeczno-gospodarczych. Był postulowany przez wybitnych przedstawicieli życia naukowego, którzy koncentrowali się na kwestiach rolnictwa, ustroju rolnego i egzystencji warstwy chłopskiej. Poglądy agrarystyczne głosił Franciszek Bujak i Wincenty Styś z Uniwersytetu Lwowskiego oraz Władysław Grabski ze Szkoły Głównej Gospodarstwa Wiejskiego w Warszawie. Reprezentowali oni tzw. nurt profesorski w rozwoju myśli agrarystycznej.

\section{GŁÓWNE ZAŁOŻENIA AGRARYZMU}

Termin agraryzm (łac. ager — rola, agrarius — dotyczący rolny) jest używany w trzech znaczeniach: ruchu społeczno-politycznego powstałego u schyłku XIX w. w Niemczech, doktryny społecznej, określającej znaczenie i funkcje warstwy chłopskiej oraz ruchu chłopskiego opartego na tej doktrynie ${ }^{1}$. Termin ten

\footnotetext{
1 W. Piątkowski, Wokót idei agraryzmu, Warszawa 1993, s. 32.
} 
wprowadził A. Schäffle na określenie ruchu zmierzającego do poprawy sytuacji w rolnictwie w związku z kryzysem agrarnym 1870-1890. W 1901 r. opublikował pracę zatytułowaną Ryzyko agraryzmu dla Niemiec (Die Gefahren der Agrarismus für Deutschland) ${ }^{2}$. Agraryzm jako ruch społeczno-ekonomiczny i polityczny zrodził się z potrzeby obrony interesów wielkich właścicieli ziemskich zagrożonych przez prężny rozwój kapitału przemysłowego i handlowego. Postulaty producentów rolnych dotyczyły wprowadzenia ceł ochronnych na zboże oraz ustanowienia państwowego monopolu na handel nim. Głównym teoretykiem i przywódcą agraryzmu w Niemczech był G. Ruhland.

W tym samym niemal czasie rozwinął się agraryzm w USA, noszący nazwę ruralizmu ${ }^{3}$. Wyrażał on interesy drobnych farmerów, którzy występowali przeciwko koncentracji ziemi, tworzeniu większych farm kosztem mniejszych i opanowaniu rynku rolnego przez wielki kapitał.

Do rozwoju agraryzmu na gruncie europejskim przyczyniły się ruchy agrarne m.in. w Szwajcarii i Danii. Głównym ideologiem agraryzmu w Szwajcarii był ekonomista E. Laur, a w Danii pisarz i pedagog N. Grundtvig. Program agrarystów zachodnioeuropejskich obejmował likwidację wyzysku rolnictwa przez kapitał przemysłowy, handlowy i lichwiarski, powstrzymanie wzrastającego zadłużenia wsi oraz wzmocnienie pozycji ekonomicznej indywidualnych gospodarstw rolnych.

Agraryzm znalazł też zwolenników w krajach południowej i środkowej Europy, m.in. w Czechosłowacji, Bułgarii i Polsce. Reprezentanci czeskiego agraryzmu: Milan Hodża, Antoni Švehla i Otokar Frankenberger ${ }^{4}$, opowiadali się za realizacją interesów ekonomicznych wsi i zwiększeniem udziału jej reprezentantów w rządach. Opracowali program reform agrarnych oparty na parcelacji wielkiej własności ziemskiej i przyznaniu praw do ziemi chłopom. Akcentowali prostotę i nieskazitelność moralną warstwy chłopskiej, jej przywiązanie do tradycji i korzeni. Ideę ojczyzny wiązali silnie z ideą ojcowizny, a więc spuścizny nie tylko w aspekcie materialnym, lecz także kulturowym. Podkreślali znaczenie interesów narodowych, wskazując na związek tego, co narodowe, z tym, co chłopskie. Głosili, że państwo umiarkowane, demokratyczne powinno być przyjazne rolnikom i dbać o ich interesy.

Radykalny agraryzm stał się ideologią Bułgarskiego Ludowego Związku Chłopskiego pod przewodnictwem Aleksandra Stambolijskiego, który opracował daleko idący program zmian ustrojowych w duchu tzw. demokracji chłopskiej5. Postulował urzeczywistnienie przewodnictwa politycznego chłopów w państwie, głosząc hasła o antyobszarniczym i antymonopolistycznym charakterze.

Agraryści, którzy podkreślali wspólnotę interesów krajów słowiańskich, powołali w 1921 r. Międzynarodowe Biuro Agrarne, będące centrum organizacyj-

\footnotetext{
2 Ibidem.

3 A. Golec, Agrarystyczne koncepcje gospodarcze, Lublin 1994, s. 41-42.

4 Ibidem.

5 W. Piątkowski, op. cit., s. 33-34.
} 
nym partii chłopskich, a w 1924 r. Słowiański Związek Młodzieży Wiejskiej, który propagował hasła reform agrarnych, likwidacji przeludnienia wsi, podniesienia kwalifikacji zawodowych rolników i rozwoju oświaty wiejskiej6.

W Polsce agraryzm zyskał zwolenników w latach 20. XX w., a jego czołowa postacią był prezes Stronnictwa Chłopskiego - Jan Dąbski ${ }^{7}$. Zainspirowany doświadczeniami agrarystów czeskich, opowiadał się za wyrównaniem różnic majątkowych na wsi. Zakładał powołanie gospodarstw chłopskich, będących typową formą własności, a podział majątków obszarniczych traktował jako akt sprawiedliwości dziejowej. Proponował podporządkowanie polityki ekonomicznej państwa potrzebom rolnictwa jako głównej gałęzi gospodarki. Postulował oparcie życia publicznego na zasadach samorządowych i demokratyczno-parlamentarnych, wskazując na konieczność przyznania chłopom większego wpływu na bieg spraw państwowych. Uważał, że należy dążyć do pogłębienia solidarności warstwy chłopskiej w skali międzynarodowej, rozwijania współpracy między narodami i utrwalenia pokoju na świcie. Poglądy Dąbskiego wywarły istotny wpływ na kształtowanie się koncepcji agrarnych w międzywojennej Polsce, które rozwijały się w trzech głównych nurtach. Pierwszy to wspomniany już tzw. nurt profesorki, skupiony w znacznej mierze na aspektach ekonomicznych. Centrum myśli agraryzmu było powołane w 1937 r. przez Zrzeszenie Inteligencji Ludowej i Przyjaciół Wsi. Nurt drugi, związany z ruchem ludowym, był reprezentowany przez Związek Młodzieży Wiejskiej RP, którego organem prasowym były Wici ${ }^{8}$. Programowe założenia tej organizacji opracował Stanisław Miłkowski. Był on twórcą podstaw ideowych, a zarazem najwybitniejszym propagatorem agraryzmu w Polsce. Duże zasługi w upowszechnianiu idei agrarnych mieli także Józef Niećko, Ignacy Solarz i Stefan Ignar. Nurt trzeci, opierający się na istniejących już koncepcjach, to ideologia stronnictw ludowych. W najszerszym zakresie doktryna agraryzmu znalazła swe odzwierciedlenie w programie Stronnictwa Ludowego, przyjętym na kongresie w 1935 r. W czasie II wojny światowej nawiązywało do niego Stronnictwo Ludowe „Roch”, a następnie Polskie Stronnictwo Ludowe. Został on natomiast odrzucony przez Stronnictwo Ludowe i Zjednoczone Stronnictwo Ludowe.

S. Miłkowski, którego poglądy odzwierciedlały idee całego ruchu ludowego, stworzył najbardziej dojrzałą koncepcję polskiego agraryzmu. Głosił, że mechanizm funkcjonowania rodziny chłopskiej, jej gospodarstwa i gromady wiejskiej w stałym kontakcie z naturą i jej prawami, z dala od cywilizacji, wykształcił wśród mieszkańców wsi pewne cechy osobowościowe, takie jak pracowitość, uczciwość, oszczędność, przywiązanie do ziemi ojczystej, które zasługują na szczególnie pozytywną ocenę z punktu widzenia życia narodu i państwa ${ }^{9}$. Reprezentowane przez warstwę chłopską wartości stawiał za wzór całemu społeczeństwu, a z ich upo-

\footnotetext{
6 Ibidem, s. 34.

7 J. Dąbski, Ideologia chłopska, Warszawa 1929.

8 W. Piątkowski, Wokót idei agraryzmu..., s. 35.

9 W. Piątkowski, Myśl agrarystyczna Stanisława Miłkowskiego, Warszawa 1983, s. 133-135.
} 
wszechnieniem wiązał nadzieje na odrodzenie moralne, a także rozwój gospodarczy. Postulował realizację interesów ekonomicznych ludności wiejskiej i budowę sprawiedliwego ustroju społeczno-gospodarczego. Nawoływał do natychmiastowego rozwiązania trudnych i złożonych problemów wsi poprzez przeprowadzenie radykalnej reformy rolnej, polegającej na wywłaszczeniu wielkiej własności ziemskiej bez odszkodowania ${ }^{10}$. Zniesienie własności obszarniczej bez wykupu i przekazanie ziemi chłopom uzasadniał koniecznością wyrównania dysproporcji majątkowych i dochodowych w społeczeństwie. Proponował oparcie ustroju rolnego na samodzielnych gospodarstwach chłopskich, które uważał za najkorzystniejszą formę organizacji stosunków w rolnictwie. Za utrwaleniem gospodarki chłopskiej przemawiała, jego zdaniem, konieczność wyeliminowania stosunków najemnych, będących przyczyną wyzysku w społeczeństwie. Wskazywał na pracę jako główne źródło bogactwa i twierdził, że właściciele ziemi powinni być jednocześnie wytwórcami dóbr.

S. Miłkowski był zwolennikiem upowszechnienia spółdzielczości w rolnictwie. Wskazywał na rolę organizacji spółdzielczych w procesie szerzenia postępu technicznego, a także likwidacji zmonopolizowanych pośredników w handlu płodami rolnymi. Wielką wagę przykładał do rozwoju spółdzielni w sferze usług niematerialnych. Twierdził, że spółdzielnie zdrowia, spółdzielcze instytucje kulturalne i oświatowo-wychowawcze przyczyniają się do likwidacji zacofania wsi i zwiększają udział jej mieszkańców w osiągnięciach cywilizacyjnych.

Dostrzegając rosnące przeludnienie wsi, Miłkowski zalecał przesunięcie części ludności rolniczej do przemysłu, handlu, rzemiosła i usług. Był zdania, że same reformy rolne nie rozwiążą tego problemu, gdyż ziemi z parcelacji może nie wystarczyć dla wszystkich chcących utworzyć własne gospodarstwa. Głosił rozwój przemysłu przetwórczego bazującego na płodach rolnych jako surowcach oraz produkującego maszyny i nawozy dla rolnictwa. Kierując się względami społecznymi, proponował zniesienie prywatnej własności kapitału i wprowadzenie w to miejsce własności samorządowej i spółdzielczej. Uważał, że przemysł ciężki należy przekazać samorządom, natomiast średni i drobny,zawłaszcza przetwórczy oraz usługi i handel zorganizować w formie spółdzielni ${ }^{11}$. Gałęzie o znaczeniu strategicznym, takie jak przemysł zbrojeniowy i infrastruktura techniczna, powinny pozostać państwowe ${ }^{12}$.

Do negatywnych stron rozwoju przemysłu Miłkowski zaliczał urbanizację. Egzystencji w mieście przeciwstawiał życie na wsi. W wielkich miastach i nadmiernej urbanizacji widział zagrożenie zdrowia mieszkańców. Był przeciwnikiem lokalizowania produkcji w dużych ośrodków miejskich. Nawoływał do racjonalnego korzystania ze zdobyczy techniki w taki sposób, aby poprzez zapewnienie

10 I. Rumianowska, J. Szapiel, Agraryzm w ujęciu Stanisława Miłkowskiego, „Polska Myśl Ekonomiczna. Prace Naukowe Akademii Ekonomicznej we Wrocławiu”, 1990, nr 542, s. 68.

11 S. Miłkowski, Agraryzm jako forma przebudowy ustroju społecznego, Kraków 1934, s. 67.

12 Ibidem, s. 45. 
ciągłego i bliskiego kontaktu człowieka z przyrodą zagwarantować mu harmonijny i zdrowy rozwój. Praktyczne rozwiązanie tego problemu miało polegać, jego zdaniem, na tworzeniu niezbyt dużych miast i otaczaniu ich przedmieściami bądź też na przenoszeniu zakładów przemysłowych na tereny wiejskie, gdzie człowiek mógł żyć w zgodzie z naturą.

Miłkowski głosił budowę ustroju gospodarczego, wolnego od wyzysku i nierówności społecznych. Konsekwencją tych haseł był postulat demokratyzacji życia politycznego poprzez realizację następujących zasad ${ }^{13}$ :

— równość obywateli wobec prawa;

— bezwzględne poszanowanie prawa i zasad moralności chrześcijańskiej w życiu publicznym;

- władza prawodawcza złożona w ręce sejmu wybieranego w głosowaniu równym, powszechnym, bezpośrednim i tajnym oraz Naczelnej Izby Gospodarczej wybieranej przez rozbudowane organizacje samorządu terytorialnego i gospodarczego;

- rząd oparty na zaufaniu mas ludowych, kontrolowany przez sejm i odpowiedzialny przed sejmem;

— sądy całkowicie niezawisłe;

- aparat urzędowy fachowy, nieliczny, odpowiednio wyposażony, niezależny od wpływów polityczno-partyjnych i bezstronny w urzędowaniu, odpowiedzialny materialnie wraz ze skarbem państwa za szkody wyrządzone obywatelom przez niedbalstwo bądź złą wolę;

— samorząd terytorialny i zawodowy, samodzielny w wykonywaniu swoich uprawnień, kontrolowany przez państwowe władze nadzorcze tylko z punktu widzenia legalności jego działań.

Miłkowski opowiadał się za decentralizacją i rozwojem samorządności lokalnej, by przybliżyć władzę do obywatela i usprawnić funkcjonowanie administracji. Proponował, aby jednostką samorządową o zasięgu ogólnokrajowym była naczelna izba gospodarcza zastępująca senat, złożona z przedstawicieli samorządu terytorialnego, związków zawodowych i spółdzielczości ${ }^{14}$. Do jej zadań zaliczył stanowienie prawa gospodarczego, nadzorowanie niższych ogniw samorządu, pełnienie funkcji właściciela środków produkcji, sporządzanie planów gospodarczych i sprawowanie kontroli nad ich realizacją. W decyzjach izby, a także niższych organów samorządu gospodarczego, odzwierciedlały się potrzeby społeczne, wobec czego funkcjonowanie gospodarki było zgodne z oczekiwaniami wszystkich obywateli. Planowanie, będące nieodłączną cechą ustroju agrarystycznego, miało przyczynić się do dostosowania produkcji do potrzeb społecznych i ich całkowitego zaspokojenia, zrealizowania zasady pełnego zatrudnienia, wzrostu inwestycji, a także wyeliminowania groźby kryzysów nadprodukcji. Wyłączając planowanie

13 I. Rumianowska, J. Szapiel, op. cit., s. 61.

14 W. Piątkowski, Myśl agrarystyczna..., s. 78. 
spod kompetencji rządu i powierzając je organom samorządowym, Miłkowski twierdził, że nie jest on zdolny do prowadzenia efektywnej działalności gospodarczej w szerszym zakresie. „Według więc zasad agraryzmu całe życie gospodarcze winno się oprzeć na społeczeństwie i organizacjach przez niego wyłonionych a państwo miałoby za zadanie sprawowanie w tym kierunku ogólnego nadzoru i opieki"15.

\section{POGLĄDYAGRARYSTYCZNEW UJĘCIU „NURTU PROFESORSKIEGO”}

\section{FRANCISZEK BUJAK}

Agraryzm znalazł swoje odzwierciedlenie nie tylko w poglądach działaczy ruchu ludowego, lecz także przedstawicieli świata nauki. Zwolennikiem agraryzmu był Franciszek Bujak, historyk dziejów gospodarczych i socjolog wsi, jeden $\mathrm{z}$ pierwszych promotorów badań interdyscyplinarnych w zakresie nauk społecznych. Bujak stworzył szkołę badawczą polskiej historii gospodarczej, zwłaszcza dziejów wsi. Prowadził szczegółowe badania obszarów wiejskich, oparte na obserwacji, wywiadzie i ankiecie, a ich wyniki prezentował w pracach monograficznych. Od 1909 r. był profesorem Uniwersytetu Jagiellońskiego, a od 1919 r. Uniwersytetu Warszawskiego i wykładowcą w Wyższej Szkole Handlowej. Następnie związał się z Uniwersytetem Jana Kazimierza we Lwowie (1921-1939), gdzie zorganizował najlepszy w okresie międzywojennym ośrodek badań historii gospodarczej Polski. W 1946 r. powrócił na UJ, a dwa lata później przeszedł na emeryturę. Współpracował z Ossolineum oraz Państwowym Instytutem Naukowym Gospodarstwa Wiejskiego w Puławach. W okresie międzywojennym, związany z PSL-Piast, był krótko ministrem rolnictwa i dóbr państwowych (VI-VII 1920), a następnie prezesem Państwowego Banku Rolnego (1926-1927). W latach 1938-1939 pełnił funkcję prezesa Zrzeszenia Inteligencji Ludowej i Przyjaciół Wsi. Jako reprezentant tego środowiska głosił, że to właśnie inteligencja pochodzenia wiejskiego powinna przejawiać szczególne zainteresowanie sprawami wsi i rolnictwa. Apelował o podjęcie działań na rzecz rozwoju gospodarczego i społecznego obszarów wiejskich. Podkreślał znaczenie pracy kulturalnej i oświatowej wśród chłopów. Dawał w tym względzie osobisty przykład, świadcząc pomoc mieszkańcom rodzinnych Maszkienic w kwestiach poprawy warunków ich bytu materialnego i podniesienia poziomu kulturalnego ${ }^{16}$.

W swoich rozważaniach na tematy związane z rolnictwem Bujak koncentrował się na sprawie reformy rolnej ${ }^{17}$. Akcentował potrzebę uregulowania sto-

15 S. Miłkowski, op. cit., s. 48-49.

16 B. Szafraniec, Franciszek Bujak (1875-1953). Życie, działalność naukowo-dydaktyczna i społeczna, Toruń 2009, s. 161-163.

17 Ibidem, s. 151. 
sunków własnościowych na wsi, chociażby ze względu na znaczenie rolnictwa jako podstawowej gałęzi gospodarki narodowej i głównego źródła utrzymania ludności. Zwracał uwagę zarówno na aspekt ekonomiczny, jak i społeczny przemian ustrojowych na wsi. Posiadanie ziemi łączył ściśle z problemem podziału dochodu w społeczeństwie. Opowiadał się za likwidacją ubóstwa na wsi, przyznając chłopom bezrolnymi i małorolnym prawo do upominania się o własne interesy ${ }^{18}$. Proponował szeroką dyskusję społeczną na temat przyszłości rolnictwa w Polsce. Przestrzegał przed podejmowaniem pochopnych decyzji, zalecał rozsądek i nieuleganie emocjom. Apel ten kierował zwłaszcza do działaczy ludowych, którzy powinni wziąć pod uwagę fakt, że przygotowanie ustawy przez rząd i jej uchwalenie wymaga czasu. Twierdził, że celem zmian powinno być zapewnienie powszechnego dobrobytu i bezpieczeństwa wszystkim obywatelom, a nie tylko wybranym grupom społecznych.

Bujak inaczej niż Miłkowski, który traktował reformę jako akt sprawiedliwości dziejowej i formę zadośćuczynienia wielowiekowego ucisku chłopów, wykluczył możliwość realizacja interesów jednej warstwy społecznej kosztem innej. Podkreślał, że konieczne jest zachowanie umiaru w przeprowadzaniu reformy, i sprzeciwiał się wywłaszczeniu bez odszkodowania. Twierdził, że istotą zmian ustrojowych na wsi powinna być likwidacja latyfundiów i ograniczenie liczby gospodarstw karłowatych, które nie są w stanie zapewnić środków utrzymania rodzinom wiejskim. Był zwolennikiem tworzenia większych gospodarstw chłopskich $^{19}$. Wyłączne istnienie małych gospodarstw, uprawianych siłami rodzin wiejskich, uznał za bezcelowe. Obawiał się, że zahamuje to postęp na wsi i utrudni odpływ nadwyżki ludności rolnej, co z kolei będzie skutkować rozdrobnieniem ziemi. Dopuszczał zróżnicowanie wielkości gruntów, akceptując istnienie zarówno dużych jak i mniejszych gospodarstw chłopskich. Nie negował też całkowicie istnienia wielkiej własności rolnej, ale pod warunkiem określenia limitu posiadania, tj. 500 ha ziemi uprawnej lub 1500 ha lasów ${ }^{20}$.

Rozwijając działalność społeczną i publicystyczną, Bujak, pod koniec lat 30., wspólnie ze Stefanem Inglotem i Wincentym Stysiem, utworzył spółdzielnię wydawniczą „Wieś”. Jej celem było wydawanie czasopisma naukowego poświęconego sprawom gospodarczym i społecznym wsi oraz innych prac z tego zakresu. Pierwszy numer miesięcznika „Wieś i Państwo”, którego redakcję stanowili założyciele spółdzielni „Wieś”, ukazał się w styczniu 1938 r. W publikowanych artykułach Bujak analizował położenie warstwy chłopskiej w społeczeństwie. Pisał o ograniczeniu praw ludności wiejskiej, pozbawieniu jej wpływu na sprawy państwowe. Niepokoił go zanik samorządności na wsi oraz słaby rozwój zrzeszeń rolniczych, realizujących określone cele ekonomiczne. Zwracał uwagę na brak

18 F. Bujak, O naprawie ustroju rolnego w Polsce, Warszawa 1918, s. 8-9.

19 Ibidem, s. 90-92.

20 B. Szafraniec, op. cit., s. 153. 
możliwości awansu społecznego chłopów, co tłumaczył barierami w dostępie do oświaty i szkolnictwa. Wskazywał na zmarginalizowanie roli włościan w społeczeństwie i zanik więzi z klasami wyższymi oraz instytucją państwa. Powierzył mu zadanie zmiany tej sytuacji i zadbania o interesy warstwy chłopskiej ${ }^{21}$.

W innym artykule Bujak zwracał uwagę na pozytywny wpływ ruchu ludowego na sytuację ludności wiejskiej ${ }^{22}$. Twierdził, że aktywność jego działaczy przyczyniła się do rozwoju szkolnictwa i oświaty na wsi. Wzrost świadomości społecznej wśród chłopów sprawił, że zaczęli uczestniczyć w życiu kulturalnym kraju, stając się nawet twórcami kultury. Dzięki temu kultura narodowa nabrała charakteru włościańskiego, a warstwy ludowe odzyskały należne im miejsce w społeczeństwie. Bujak pragnął, aby temu procesowi towarzyszył postęp gospodarczy. Podniesienie kultury rolnej wiązał z rozwojem organizacji społecznych i gospodarczych oraz upowszechnieniem spółdzielczości na terenach wiejskich ${ }^{23}$.

\section{WINCENTY STYŚ}

Z lwowskiego ośrodka naukowego wywodził się Wincenty Styś, który kształcił się w Katedrze Historii Społeczno-Gospodarczej, kierowanej przez F. Bujaka. Jeszcze jako student prawa uczęszczał na wykłady Stanisława Grabskiego, czołowego przedstawiciela nurtu historycznego w międzywojennej ekonomii. Od swojego mistrza przyswoił sobie założenia „,socjologizmu historycznego”, którego twórcą był S. Grabski, i podobnie jak on poszukiwał w działaniach gospodarczych, podlegających ewolucji, aspektów społecznych. Obszarem badawczym, w którym stosował metodę Grabskiego, było rolnictwo, co ze względu na pochodzenie chłopskie było rzeczą niejako naturalną. Uczestniczył w seminarium z ekonomii, prowadzonym przez S. Grabskiego, w którego trakcie zapoznał się z literaturą dotyczącą rozwoju rolnictwa na ziemiach polskich w XIX i XX w. W 1930 r. został przyjęty na stanowisko asystenta w kierowanej przez niego Katedrze Ekonomii Społecznej, a w 1932 r. doktoryzował się na podstawie rozprawy poświęconej kształtowaniu się struktury rolnej we wsiach południowej Polski²4. W pracy habilitacyjnej z $1936 \mathrm{r}$. zajął się oddziaływaniem przemysłu na stan gruntów rolnych ${ }^{25}$.

Po wojnie Styś przeniósł się do Wrocławia, gdzie objął stanowisko profesora i kierownika Katedry Ekonomii na Wydziale Prawa Uniwersytetu Wrocławskiego. Razem z profesorem Kamilem Stefką, założył w 1948 r. Wyższą Szkołę Handlo-

${ }^{21}$ F. Bujak, Wieś i państwo, „Wieś i Państwo”, Lwów 1938, nr 1, s. 10-12.

22 F. Bujak, Chłop wyrazicielem ducha Polski, „Wieś i Państwo”, Lwów 1938, nr 7, s. 487.

23 Ibidem, s. 488.

24 W. Styś, Rozdrobnienie gruntów chłopskich w bylym zaborze austriackim od roku 1787 do 1931, Archiwum Towarzystwa Naukowego we Lwowie, Lwów 1934, t. 15, z. 1.

25 W. Styś, Wpływ uprzemystowienia na ustrój rolny, Archiwum Towarzystwa Naukowego we Lwowie, Lwów 1936, t. 16, z. 4. 
wą, prywatną szkołę wyższą, którą następnie upaństwowiono jako Wyższą Szkołę Ekonomiczną. Był profesorem tej uczelni i kierował Katedrą Ekonomii. Wykładał też w Wyższej Szkole Rolniczej i Politechnice Wrocławskiej. Był jednym z organizatorów wrocławskiego Oddział Polskiego Towarzystwa Ekonomicznego i jego pierwszym prezesem. Działał też aktywnie na rzecz zagospodarowania i zasiedlenia Ziem Zachodnich. Prowadził szeroko zakrojoną akcję na rzecz organizacji osadnictwa spółdzielczego na Dolnym Śląsku. Równolegle kontynuował badania nad zmianami ustrojowymi w rolnictwie, przenosząc na grunt wrocławski tradycje szkoły historycznej w ekonomii. Wzorował się na procedurach badawczych „szkoły bujakowskiej", które znacznie rozwinął i udoskonalił. Korzystał z materiałów źródłowych oraz prowadził pracochłonne badania empiryczne oparte na wywiadzie i ankiecie. Jego prace oprócz historycznego nosiły także teoretyczny charakter.

W. Styś był znawcą problemów rolnictwa. Interesował się warunkami gospodarowania i życia na wsi. Badał społeczne aspekty przeobrażeń struktury agrarnej, dowodząc znaczenia stanu zaludnienia dla kształtowania się układu własności w rolnictwie. Okrył prawidłowość polegającą na rozpadzie gospodarstw chłopskich i spadku ich przeciętnej wielkości na skutek przeludnienia wsi. Twierdził, że wzrost liczby osób pracujących na roli jest bezpośrednią przyczyną rozdrobnienia gruntów. Naprawę stosunków w rolnictwie uzależniał od odpływu nadmiaru siły roboczej do przemysłu. Uważał, że w ten sposób można zmniejszyć nacisk ludności na strukturę rolną i powstrzymać proces skarłowacenia gruntów. Zmiana rozmieszczenia zasobów pracy w gospodarce wywołuje pozytywne zmiany w rolnictwie. Następuje wzrost przeciętnych rozmiarów gospodarstw chłopskich, w wyniku czego zwiększa się efektywność i opłacalność produkcji rolnej ${ }^{26}$. Wnosząc istotny wkład w rozwój teorii renty gruntowej, Styś uznał uprzemysłowienie za istotną przesłankę optymalizacji organizacji rolnictwa i zwiększenia dochodu z ziemi27.

W celu rozwiązania problemów ludności małorolnej i bezrolnej W. Styś nie wykluczał także emigracji zarobkowej ${ }^{28}$. Mając świadomość ciężkich warunków życia i niskich zarobków polskich emigrantów, uważał emigrację za środek doraźny, służący poprawie stanu rolnictwa do chwili, aż produkcja przemysłowa rozwinie się tak, że będzie w stanie wchłonąc nadmiar osób pracujących na wsi. Twierdził, że odpływ siły roboczej za granicę ma swoje ujemne konsekwencje, gdyż prowadzi do strat w jej zasobie, co może poważnie osłabić rozwój sił wytwórczych kraju. Wstrzymanie ruchu emigracyjnego wiązał raczej z uprzemysłowieniem aniżeli z reformami rolnymi, których pozytywne skutki są odczuwalne tylko wówczas, gdy nadmiar ludności wiejskiej znajduje zatrudnienie w innych działach gospodarki. W przeciwnym wypadku wpływ reform na ustrój rolny szyb-

26 Ibidem, s. 219.

27 W. Styś, Ekonomia. Fragment skryptu z wykładów na Wydziale Rolniczo-Lasowym Politechniki Lwowskiej, Archiwum Polskiej Akademii Nauk w Warszawie, sygn. III-136, jedn. 46, 1936-1939, s. 73-74.

28 W. Styś, Emigracja ludności wiejskiej, Lwów 1938. 
ko podlega niwelacji, gdyż wraz ze wzrostem stanu posiadania zwiększa się także przyrost naturalny, co nasila proces rozdrobnienia własności ${ }^{29}$.

Opierając się na wynikach swych badań nad przyczynami i przebiegiem zmian strukturalnych w rolnictwie, Styś głosił, że tylko równomierny rozwój wszystkich gałęzi produkcji jest $\mathrm{w}$ stanie powstrzymać proces podziałów własności. Zakładał połączenie działań zmierzających do uprzemysłowienia kraju z reformami mającymi na celu wyrównanie różnic majątkowych w społeczeństwie. Twierdził, że akumulacja bogactw w ręku nielicznych utrudnia do nich dostęp pozostałym, co prowadzi do biedy w społeczeństwie. Opowiadał się za upowszechnieniem własności i powiązaniem jej rozmiarów z pracą, której nakład powinien decydować o udziale w wytworzonym dochodzie. Był zwolennikiem zwiększenia chłopskiego stanu posiadania ziemi i zapewnienia każdej rodzinie pracy we własnym gospodarstwie. Proponował parcelację majątków obszarniczych, a także dużych gospodarstw chłopskich, które przyczyniają się do proletaryzacji i ubóstwa na wsi. Opowiadał się za rozwojem własności średniorolnej, a jej przewagę nad innymi formami gospodarowania na wsi uzasadniał względami ekonomicznymi, najwyższą rentownością produkcji i społecznymi, wskazując, że zapewnia sprawiedliwy podział wytworzonego dochodu, odpowiadający nakładom pracy.

Styś prezentował model organizacji rolnictwa odznaczający się przewagą samodzielnych gospodarstwach chłopskich. W celu usunięcia barier hamujących rozwój rolnictwa proponował upowszechnienie spółdzielczości na wsi. Wraz z rozwojem współdziałania i samopomocy wiązał nadzieję na wzmocnienie siły ekonomicznej indywidualnych gospodarstw. Był zwolennikiem tworzenia spółdzielni mechanizacyjnych, szerzących postęp techniczny na wsi ${ }^{30}$. Podkreślał potrzebę rozwoju spółdzielczych instytucji oświatowych i kulturalnych. Uważał, że spółdzielnie są doskonałą alternatywą wielkiej własności kapitalistycznej, która korzysta z pracy najemnej, ale też upaństwowionej gospodarki, która nieracjonalnie wykorzystuje zasoby, o czym przesądza brak właścicieli czynników produkcji. Ustrój oparty na własności rodzinnej i spółdzielczości pozwala jednostkom swobodnie dysponować pracą i kapitałem, realizować swe cele i plany, a ponadto zapewnia sprawiedliwość społeczną, co Styś bardzo mocno podkreślał.

Stojąc na stanowisku, że zadaniem państwa jest zapewnienie swobodnego rozwoju przedsiębiorczości prywatnej i wyrównywanie szans w społeczeństwie, Styś za istotne narzędzie jego ingerencji uznał prawo odzwierciedlające ideę równości. Państwo, dysponując systemem prawnym, jest zdolne do zapewnienia pokoju społeczne poprzez zwiększenie dostępu jednostek do własności. Nie odmówił mu także wpływu na gospodarkę, a za najskuteczniejszy środek regulacji uznał planowanie, które umożliwia dostosowanie produkcji do potrzeb społecznych,

29 W. Styś, Rozdrobnienie gruntów chłopskich w bytym zaborze austriackim..., s. 315.

30 W. Styś, Drogi postępu gospodarczego wsi. Studium szczegółowe na przykładzie zbiorowości próbnej wsi Husowa, „Prace Wrocławskiego Towarzystwa Naukowego”, Wrocław 1947, seria A, nr 4, s. 133-134. 
przez co chroni gospodarkę przed wahaniami koniunktury i sprawia, że może się ona szybciej rozwijać ${ }^{31}$. Do istotnych zadań państwa zaliczył także stabilizowanie systemu gospodarczego i zapobieganie kryzysom za pomocą odpowiednich narzędzi polityki fiskalnej i monetarnej.

Styś uważał wolność za podstawę systemu gospodarczego i pragnął, aby podobne zasady obowiązywały w sferze polityki. Twierdził, że ład gospodarczy i polityczny warunkują się wzajemnie, co sprawia, że nie do pogodzenia jest postępowanie według zasad rynkowych $\mathrm{w}$ gospodarce $\mathrm{z}$ odrzuceniem reguł demokratycznych w dziedzinie funkcjonowania organów władzy. Krytykował inne, poza demokratycznymi, formy rządów, dowodząc, że systemy autorytarne nie uznają zwykle swobody działania i wolnej konkurencji, a w zamian posługują się środkami przymusu, co nie służy dobrze ani społeczeństwu, ani gospodarce. Twierdził, że demokracja to jedyny ustrój, który urzeczywistnia wpływ wszystkich obywateli na bieg spraw państwowych, a nie tylko wybranej grupy czy klasy, oraz w którym interes społeczny jest wyznaczany przez ogół obywateli, a nie przez aparat państwa.

\section{WŁADYSŁAW GRABSKI}

Trzeci z przedstawicieli „nurtu profesorskiego” - Władysław Grabski polityk i ekonomista, zajmował się historią, ekonomią i socjologią wsi. W swojej pracy naukowej koncentrował się na zagadnieniach związanych z naprawą ustroju rolnego. Zasłynął jako twórca reformy walutowej z 1924 r. Związany ze Szkołą Głównej Gospodarstwa Wiejskiego w Warszawie, w której od 1923 r. był profesorem, a w latach 1926-1928 rektorem. W latach 1928-1934 przewodniczył Towarzystwu Ekonomistów i Statystyków Polskich. W 1936 r. założył (w ramach SGGW) Instytut Socjologii Wsi, który z jego inicjatywy wydawał „Roczniki Socjologii Wsi" (1936-1938).

W. Grabski był ekspertem w dziedzinie rolnictwa i polityki agrarnej. Napisał wiele prac monograficznych na ten temat. Prowadził źródłowe badania nad historią rozwoju polskiego rolnictwa oraz sytuacją ludności wiejskiej. Twierdził, że istniejący sposób organizacji rolnictwa nie gwarantuje wzrostu wydajności ziemi ani poprawy warunków życia na wsi. Zwracał uwagę na przestarzałą strukturę agrarną, która utrudnia walkę z przeludnieniem wsi. W celu rozwiązania tego problemu proponował pracę nad uprzemysłowieniem kraju. Uważał, że odpływ nadmiaru ludności ze wsi do innych zawodów przyczyni się do pełniejszego wykorzystania czynników produkcji zarówno w rolnictwie, jak i w przemyśle. Nie popierał natomiast emigracji zarobkowej, będącej efektem biedy i braku szans na

31 W. Styś, Radziecka gospodarka planowa widziana oczami planisty, „Nauka i Sztuka”, Warszawa 1948, t. 9, s. 11. 
znalezienie pracy w kraju. Powstrzymanie odpływu ludności za granicę uzależniał od rozwoju przemysłu w miastach.

Wskazując na trudne warunki gospodarowania i życia na wsi, Grabski wysuwał na pierwszy plan problem reformy rolnej. Jej przeprowadzenie mogłoby zapewnić lepszą redystrybucję dochodu społecznego, a co za tym idzie - także poprawę sytuacji ekonomicznej chłopów. Był zwolennikiem parcelacji wielkiej własności i zaspokojenia głodu ziemi małorolnych i bezrolnych chłopów. Opowiadał się za powołaniem samowystarczalnych gospodarstw chłopskich o powierzchni 5-10 ha ${ }^{32}$. Twierdził, że gospodarstwa włościańskie górują nad innymi formami organizacji produkcji rolnej pod względem wydajności pracy i kosztów produkcji. Zgodnie z doktryną agrarną dowodził, że dysponowanie własnością i dochodem stanowi podstawowy warunek wzrostu produkcji w rolnictwie. Akcentował znaczenie pracy jako głównej przesłanki udziału we własności ziemi i wytworzonym dochodzie. Uważał, że tylko powiązanie człowieka z wynikami jego pracy może zwiększyć efektywność rolnictwa i zapewnić dobrobyt na wsi. Opowiadał się za dobrowolną parcelacją, a przymusową proponował objąć wyłącznie grunty leżące odłogiem lub źle użytkowane ${ }^{33}$. Głosił hasła rozwoju gospodarstw rolnych o różnym profilu działalności, uznając, że specjalizacja produkcji przyczynia się do maksymalizacji korzyści gospodarczych ${ }^{34}$. Jednocześnie nie wykluczył całkowicie istnienia własności obszarniczej, ale tylko tej o rozmiarach do 250 ha, wskazując na korzyści z zastosowania uprawy mechanicznej ${ }^{35}$.

Podobnie jak Bujak, Grabski kładł nacisk na obowiązki inteligencji wobec warstwy chłopskiej. Podkreślał jej rolę w procesie szerzenia oświaty i kultury na wsi. Akcentował znaczenie działań na rzecz organizacji szkolnictwa wiejskiego, dzięki którym zmniejsza się obszar biedy i ubóstwa ${ }^{36}$. Twierdził, że poprzez edukację można pobudzić aktywność jednostek, które chętniej podejmują działania na rzecz poprawy własnego losu. Wielką wagę przykładał także do rozwoju współdziałania na wsi. Proponował tworzenie zrzeszeń, towarzystw i kółek rolniczych, powierzając im zadanie realizacji określonych zadań ekonomicznych. Dawał w tym względzie osobisty przykład, dążąc do upowszechnienia nowoczesnych metod produkcji w rolnictwie. Założył doświadczalną stację rolniczą w Kutnie (1899), spółdzielnię rolniczą „Spójnia” pod Kutnem (1901), Towarzystwo Melioracyjne w Warszawie (1904), kółko rolnicze i spółdzielnię mleczarską w Bocheniu (1904) oraz udziałowe stowarzyszenie rolniczo-powiatowe w Łowiczu (1905). W latach 1901-1906 pełnił funkcję sekretarza Sekcji Rolnej, z której powstało

32 A. Lityńska, Polska myśl ekonomiczna okresu międzywojennego, Kraków 2001, s. 32.

33 Ibidem, s. 32-33.

34 Ibidem, s. 33.

35 W. Grabski, Wieś i folwark. Drobne i duże gospodarstwa rolne ze stanowiska ekonomicznego, Warszawa 1930, s. 82.

36 W. Grabski, Wybór pism, Warszawa 1987, s. 124. 
Centralne Towarzystwo Rolnicze, zrzeszające właścicieli ziemskich i bogatych chłopów.

W kwestii roli państwa w gospodarce Władysław Grabski opowiadał się za realizacją polityki antykryzysowej, będąc równocześnie przeciwnikiem etatyzmu.

\section{PODSUMOWANIE}

Reprezentanci tzw. nurtu profesorskiego w rozwoju myśli agrarystycznej dążyli do sformułowania programu rozwoju gospodarczego kraju, którego podstawą miała być właściwa polityka agrarna. Wskazywali na potrzebę przeobrażeń strukturalnych i uporządkowania kwestii własnościowych na wsi. Sformułowali program reform rolnych, który mieścił się w granicach zakreślonych przez dotychczasowe ustawodawstwo, co oznaczało wykup ziemi przez państwo i przekazanie jej bezrolnym oraz małorolnym chłopom. Uważali, że odebranie ziemi właścicielom bez jakiejkolwiek rekompensaty doprowadzi do naruszenia harmonii w społeczeństwie. Odrzucili postulaty radykalnych agrarystów, którzy domagali się parcelacji wielkiej własności ziemskiej bez odszkodowania. Z drugiej strony wykluczyli możliwość pozostawienia stosunków rolnych w dotychczasowym kształcie, z uwagi na narastające dysproporcje majątkowe na wsi. Proponowane przez nich wizje organizacji rolnictwa różniły się od siebie. Bujak dopuszczał istnienie gospodarstw chłopskich różnej wielkości, a więc także tych większych, opartych na pracy najemnej. Natomiast W. Styś i W. Grabski proponowali zwiększenie stanu posiadania najniższych warstw ludności wiejskiej i oparcie ustroju rolnego na rodzinnych gospodarstwach chłopskich. Twierdzili, że ziemię może posiadać tylko ten, kto na niej pracuje. Głosili pogląd o znaczeniu pracy jako głównego źródła bogactwa, uznając ją za podstawową przesłankę udziału we własności i wytworzonym dochodzie. Styś postulował zniesienie prywatnej własności ziemi wszędzie tam, gdzie jest ona źródłem wyzysku i narusza zasady sprawiedliwości społecznej. W. Grabski i F. Bujak nie wykluczali natomiast całkowicie istnienia wiejskiej własności ziemskiej. Inaczej niż większość agrarystów, którzy postulowali rolnictwo jako podstawę gospodarki, zapominając o rozwoju innych gałęzi wytwórczości, Styś na plan pierwszy wysuwał kwestie uprzemysłowienia. Był świadom, że bez dynamicznego rozwoju przemysłu nie uda się stworzyć nowych miejsc pracy w gospodarce i rozwiązać problemu ubóstwa na wsi.

Franciszek Bujak, Wincent Styś i Władysław Grabski w pełni podzielali wnioski płynące z doktryny agrarnej o konieczności szerzenia oświaty i szkolnictwa wśród ludności wiejskiej oraz podniesienia kultury rolniczej. Osiągnięcie tego celu uzależniali od rozwoju spółdzielczości na wsi. 


\section{AGRARIANISM AND ITS EXPRESSION \\ IN THE SOCIO-ECONOMIC IDEAS \\ OF F. BUJAK, W. STYS AND W. GRABSKI}

Summary

Scientific interests of F. Bujak, W. Stys and W. Grabski focused on agriculture and agricultural policy. During the inter-war period, they represented the so-called professorial trend in the development of the agrarian thought. They pointed out the need to improve the situation of the peasants and introduce an agricultural reform. While supporting the dissemination of property, they advocated for increasing the amount of land owed by peasants. Additionally, they suggested buying land by the state, and opposed to the parceling land without compensation. They also advocated for building a fair socio-economic political system, and liquidation of exploitation. Finally, they underlined the importance of cooperatives in the process of spreading economic and civilization progress in rural areas. 